\title{
Forum
}

\section{The Cham Bani of Vietnam}

\author{
Ba Trung Phu
}

\section{Introduction}

Based on 1989 statistics, approximately 131,282 Cham live in Vietnam. They are the descendents of Champa, an Indian-Hindu kingdom that, centuries later, was heavily influenced by Arabic-Islamic culture. Buddhism also made its way into Champa, but was confined to the royal circle during the reign of King Indravarman II (c. 896-905). Historically, the Cham were divided along religious lines: Hindu and Muslim. The Muslim population is subdivided further between the Cham Banis and the mainstream (Sunni) Cham Islam. The Cham population is concentrated mainly in the lowermiddle and southern parts of Vietnam. In the middle part, they live scattered in the Phan Rang and Phan Ri regions. In the southern and southwestern parts, they live in Tay Ninh, Chau Doc, An Giang, Ho Chi Minh City, Long Khanh, and Binh Phuoc cities. The Cham Banis and Cham Hindus only reside in Phan Rang and Phan Ri. There, the Cham Banis make up about onehalf of the Cham population, while the remaining half is Cham Hindu. However, in the south and southwest, all of them follow mainstream Islam.

\section{Islam Appears in Champa}

According to Ed Huber, Islam entered Champa during the tenth century. He based this on a Chinese record: "There were many water-buffalos that lived on the mountain (in Yin Li). They (the buffalos) were not used to cultivate the land but as sacrificed objects to the gods. When the water-buffalo was killed, they invoked the name "Allahu Akhar."'1

Ba Trung Phu has a M.A. (1996) in political science from the Multi-Discipline University (Dai-Hoc Tong-hop) of Ho Chi Minh City, Vietnam. A Cham Bani, he is a member of Ho Chi Minh City's Archeological Museum and manager of the Cultural Development Center for Minority Affairs. This article was translated by Sean Tu, BSEE (1988) from Iowa State University, a Cham Islam from Phan Rang, Vietnam, and a senior test analyst at Raytheon. 
Aymonier found this paragraph in the record left by an anonymous historian of Champa:

In the year of the mice, a man who attributed himself to Po Auloah (Allah) worked for betterment and perfection of Champa. But the people became upset. He then submitted himself wholly to God, migrated to live in the holy land of Mecca. Later, he returned to the kingdom in the reign of the king whose name is Ouloah (Allah) that ruled the land from 1000 to $1036{ }^{2}$

This paragraph was carved, along with its Sanskrit translation, on two stones found by an archaeologist working along the coast of middle Vietnam. One stone was dated 1039, and the other between 1025-35. The writings on both stones mentioned Muslims, but indicated that they were foreigners who stayed along the coast in the middle of present-day Vietnam. Most of them were traders and builders who formed their own communities with a spiritual leader and a man who led the prayers, whom they called emüm (imam). Based on archaeological artifacts and historical data, some historians have concluded that Islam entered Champa perhaps as early as the tenth century.

\section{The Cham Bani}

Those Cham who follow mainstream Islam are concentrated in south and southwestern Vietnam form their own palei (villages), each of which must have at least a sang mügik (mosque), where all activities, whether social or political, are conducted. Actually, the term sang mügik is used by both the Cham Bani and the Cham Islam for their place of worship. The life and daily activities of the Cham Islam are guided by the Qur'ün (Qur'an) and its teachings. Other decisions in daily life are made by the ong kaem (hakim), a local spiritual leader who chairs every meeting in the sang mügik or resolves disputes between Muslims in the village. On the other hand, all laypeople who belong to the Cham Bani communities live freely outside the realm of orthodox Islam, for all religious responsibility rests squarely upon the acars (priests), who are responsible for safeguarding the religion from corruption and praying on the community's behalf.

\section{Religious Creeds}

God, known among them as Po Auloah, is considered to be the One God (Allah) of the Muslims. They believe in the angels, the Qur'an, the saints (viz., the Forty Imams), and the deities (yang). Their version of the Qur'an is incomplete, for it does not contain all 114 surahs; rather, it is a collection of different surahs. No one knows what happened to the rest of them, but his- 
tory shows that the Cham have survived many centuries of war and have had virtually no contact with the outside world, especially the Muslim world, since the late fifteenth century. The Bani priests relied on their memory to write down the surahs, after their final defeat by the Vietnamese, with instructions in the Cham Sanskrit-based script on how to use them.

The Bani Qur'ün consists of the short surahs (surahs 96-114) handwritten in the Kufic style; other surahs are either fragmented or non-existent. So when the acars spend time mastering the Qur' $u ̈ n$, they try to understand how each surah or verse is applied to a particular occasion, such as performing the religious duties associated with burials, weddings, prayer, and sermons, or to master such secular knowledge as the calendar or the lunar cycle in order to determine the beginning and end of Ramadan.

Prophet Muhammad, whom the Bani call Mbi Muhammad (Nabi Muhammad), is a rather vague figure. They do not know what country he came from or to which race he belonged. All they know is that he is the man whom Po Auloah sent. Also interesting is that they call Ali, his cousin and son-in-law, Mbi Ali, meaning that Prophet Muhammad and Ali are on the same level. The Bani sermons, handed down for many generations, mention Fatimah next to Ali, but they do not know who she is.

\section{Religious Hierarchy}

The religious life of the Bani communities rests upon the circle of male acars, who are responsible for performing all religious duties on the community's behalf. Their structure consists of several layers, from the lowest to the highest rank, as follows: acar, madin or madintan, tip or ktip (one who gives the khutbah), emüm or emümtan, and po gru (honorable guru). Before entering into this circle, each family's maternal line ${ }^{3}$ chooses one, two, or maybe more individuals (this depends upon the family's size).

Before a candidate can become an acar, he must take a ritual bath (ghusl), shave his head and wear a white cloak, and spend several months memorizing the Qur'ün passed down through the generations in order to learn the necessary religious rituals. The Qur'ün was handcopied word-forword by their forefathers and recited; however, due to their living in isolation for so many generations, the acars do not understand what the scriptures say. Nevertheless, they consider it a holy book that cannot be abused or disrespected in any way. The acars are bound by the hierarchy of the priesthood order. Any acar who violates the religious creeds is asked to make atonement (ngap bah [tawbah]) for them in front of Po Auloah). These are the general rules and characteristics of the Bani's priesthood circle. 
Each layer of the hierarchy has a different set of rituals to perform. The acars, the first tier, divide the laypeople from the priesthood. Once they enter this layer, they are assigned to perform jamak (jum 'ah) and talavi (tarawih). Talavi is performed only during Ramadan. When an acar becomes a madin, he is called a madintan. Those who belong to this tier are responsible for organizing and orchestrating all rituals in the sang mügik and for teaching the Qur' $\ddot{u}$ n to the children. Each order has only one tip, and there is only one order per village. This official also gives the Friday khutbah, for it is not allowed to be given at home.

The acars have to spend from ten to fifteen years studying and mastering the Qur'ün and many rituals in order to become an emüm. When a tip becomes an emüm, he is called emümtan. An emüm is considered a master. Some of them are elevated to the status of an emüm pak pluh (the Forty Imams) who not only master many disciplines but are also considered outstanding people and, therefore, earn the people's trust in their fields. Once selected to become an emüm pak pluh, many po grus and emüms from different villages are invited, before a special ceremony, to present this candidate to the Forty Imams, who are part of the Bani's legendary history. No one knows who they are any more. Since this event does not occur very often, the Cham Bani regard it as a very special event that every low and high acar from near and far-away villages comes to attend.

Each village can have one or two po grus, depending upon the population, and they are nominated and selected by the acars and the villagers. He runs the sang mügik, decides important dates (e.g., when Ramadan and the Eids start), and settles disputes in religious or personal matters as well as between families.

\section{Advancing between Tiers}

The acars advance to the next tier through a specific procedure. Looking at the acar order carefully, one notices that there are two stations that have only one priest: the gru and the tip offices. Only one individual can hold this office at a given time. So, the priests can only advance when either of these two offices becomes vacant. For example, an emüm can become a gru only when the po gru passes away. In this case, the most senior emüm will hold the office. Likewise, a madin can become a tip only when the latter is promoted to an emüm. Here, the interesting point is that when the tip is advanced, it ripples through the two lower tiers, meaning that one of the madins will move up to take the tip's office and one of the acars will advance to the madin's office. The tip is promoted on Eid al-Fitr, the last 
day of Ramadan. When this happens, a ceremony is held at the sang mügik both for the candidates and with the spouses of the tip, the madin, and the acar. In normal operation mode, each sang mügik nominates three different groups (viz., the emüm din [assistant imam]), the tip [khatib], and the emüm [imam] for a three-year period of service to the community. This period also serves as a trial period for those who desire to be promoted to a higher rank.

The Cham Bani are not bound by orthodox Islam's religious creeds as are the Cham Islam, who are mainstream Sunni Muslims. The Cham Islam believe in Allah and that Muhammad is His messenger, pray five times a day, attend the Friday prayer at the mosque, pay zakat, and perform hajj at least once in a lifetime. Making the pilgrimage to Makkah is a must for those who have the means. In the Southeast Asian tradition, those who came back from the hajj are called hajji, which signifies that they have fulfilled this pillar.

The Cham Bani laypeople, on the other hand, perform none of these rituals because they believe that their representative acar in the religious order has already fulfilled them for the community. Moreover, a long-standing tradition handed down through the generations mandates that each family's maternal line dedicate their own man in the line of religion to perform all religious duties and to intercede for them with Po Auloah. As a result, the Cham Bani laypeople are not bound by the five pillars of Islam. The priests do not have to make the pilgrimage to Makkah, and instead of paying zakat in the form of distributing money to the poor, the Cham Bani community contributes rice, a very common commodity in Vietnam, to the acars in their own family line.

For the Cham Islam, the mosque is also a place for socializing, settling disputes, performing such religious ceremonies as weddings, and praying for blessing. On the contrary, the Cham Bani sang mügik is open only during Ramadan and for such important events as Friday prayers.

\section{The Ramadan Fast}

For mainstream Muslims, the Ramadan fast is one of Islam's five pillars and is compulsory for each Muslim who can fast. Every year, Ramadan provides a boost in spiritual renewal. In southern and southwestern Vietnam, the Cham Islam begin and end their fast based on a calendar created by Haji Isahat. ${ }^{4}$ This calendar shows all of the important religious events with crossreferences to the lunar and solar cycles to make it easy to follow.

When Ramadan comes, Muslims celebrate two occasions: one before and another one after Ramadan (Eid al-Fitr). Ramadan has a special mean- 
ing in their lives. Interestingly, for both the Cham Muslims and the Muslims in Southeast Asia in general, during this month daily activities almost come to a stop during the day but come alive during the night.

The Cham Bani call Ramadan Ramüvan. Considering it more like a month of worshiping Po Auloah, they dedicate their sincerity to the Forty Imams rather than to fasting. During this month, every acar must be present in the sang mügik. Normally, devout orthodox Muslims stay in the mosque for the last ten days ( $i^{\prime}$ tikaf); however, the acars must stay inside the whole month. Before Ramüvan starts, the Bani priests in every tier must perform the ngap bah (tawbah) ceremony, and every house in the village must perform the cleansing ceremony. Each ceremony has its own merits and procedures, which are, unfortunately, beyond the scope of this article. The acar must perform his own ngap bah ceremony and then go from house to house to perform the cleansing ritual for the layman families. After that, they stay in the sang mügik. Every afternoon during this month, the acar's family brings food for them to break their fast. Other family members contribute rice to support the acar's family while he remains inside.

Cham Bani tradition holds four days during Ramüvan in high esteem: the first, the fifteenth (full moon), the twentieth, and the thirtieth (the last day). On these four occasions, every family in the village brings rice and sweets to the sang mügik for the acars and worships there to get a blessing for their family. Unlike the Cham Islam, who go home after tarawih, the Cham Bani remain in the sang mügik during the night because it houses all the village's acars. They also visit it wearing white garments to invoke blessings from Po Auloah.

During this month, the Cham Hindu priests, called ong sak and ong seh (high priests), also visit the Cham Bani acars. This tradition is observed by both groups of Cham to maintain harmony within Champa. The Cham Hindu priests confess that Po Auloah is the Supreme Being and pray to Him for His blessing. On special nights called ong troon muk troon (Ramadan 27), some Cham Hindus bring fruits and sweets to the sang mügik to offer to Po Auloah and pray along with Cham Bani acars. Perhaps such a mixture of two very different religions coming together in the house of God only exists in the Cham Bani community.

\section{Building the Sang Mügik}

Oral transmissions from many village elders say that prior to the twentieth century, all sang mügiks were built with unique specifications: the roof had to be made of fine long grass from the mountain, the walls with fine bamboo, 
and the floor with plain dirt. These items may have had symbolic meanings, but no one knows them any more. In front of the entrance, there were seven plain rocks and a container for the water used by the acars to make ablution (wudu').

These days, however, all of these structures are built and fortified with a cement floor, a brick wall, and a tile roof. They do not have a dome or a dome-like shape like mosques throughout the world. However, they are all oriented toward Makkah so that the acars can face the holy city during their prayers. At the end of western wall, there is a canopy supported by four posts. This is the place where the tip stands up to give the Friday sermon. They call this place the mimbar, just as the orthodox Muslims do. The main activities carried out in the sang mügik occur during Ramadan and on some special Fridays called sut yeng (rotated Friday) or zam-at (jum 'at). ${ }^{5}$ The celebration of wa-ha (Eid al-Adha) has its own special place among the Cham Bani, not like the Muslims. For this event, the acars fast on the first day of Dhu alHijjah at home. On the tenth day, all acars pray at the sang mügik, just like the Muslims. The Cham Bani do not perform qurban (the sacrifice) on Eid al-Adha, but every family prepares sweet dishes and takes them to the sang mügik for the acars to enjoy.

\section{Conclusion}

The Cham Bani have preserved their traditional Islamic faith and mixed it with local customs and traditions, thereby creating a unique variety of Islamic beliefs and rituals. The facts that they still pray facing Makkah, profess Po Auloah (Allah), and observe many Islamic events prove that Islam entered Champa but gradually changed to adapt to the surrounding environment and culture. Islam became a mix of traditional beliefs associated with the region's pre-Islamic Hindu deities and saints. Aa a result, Islam among the Cham Bani of Vietnam has become a unique religion, one very unlike the mainstream Sunni Islam that we see in Southeast Asia and the larger Islamic world.

\section{Endnotes}

1. E. Huber, "Note sur un témoignage de l'islamisation du Campa," Annales des Song (1903).

2. Aymonier, Le Cambodge (Paris: 1904), T.11, page 153

3. Cham society is matrilinear.

4. Haji Isahat is from Chau Doc, the Cham religious center, and might have graduated from the local university of religious education. He traveled to Malaysia 
and Cambodia to study Islam for one or two years. It is not known how he came up with the lunar calendar [translator's note].

5. Sut yeng (rotated Friday) is done once every three years in a Cham Bani community. When the cycle comes, the acars in every village gather on Friday at one village and then rotate to another until all villages have been covered. Since the Cham Banis in the Phan Rang area are divided into seven villages, there are seven rotations. This is a fun event, because every village has a chance to host acars from other villages. The purposes of sut yeng are to promote harmony among the Cham Bani, deal with new issues that arose during the last three years, and plan for the next three years. There is an open discussion among the acars as well as the ong sak and the ong sek from the Cham Hindu communities [translator's note].

The Cham Bani of Phuoc Nhung village, Ninh Thuan province, Vietnam, performing talavi (the tarawih prayer) during Ramadan 1993. (Photo: Courtesy of Jay Willoughby)

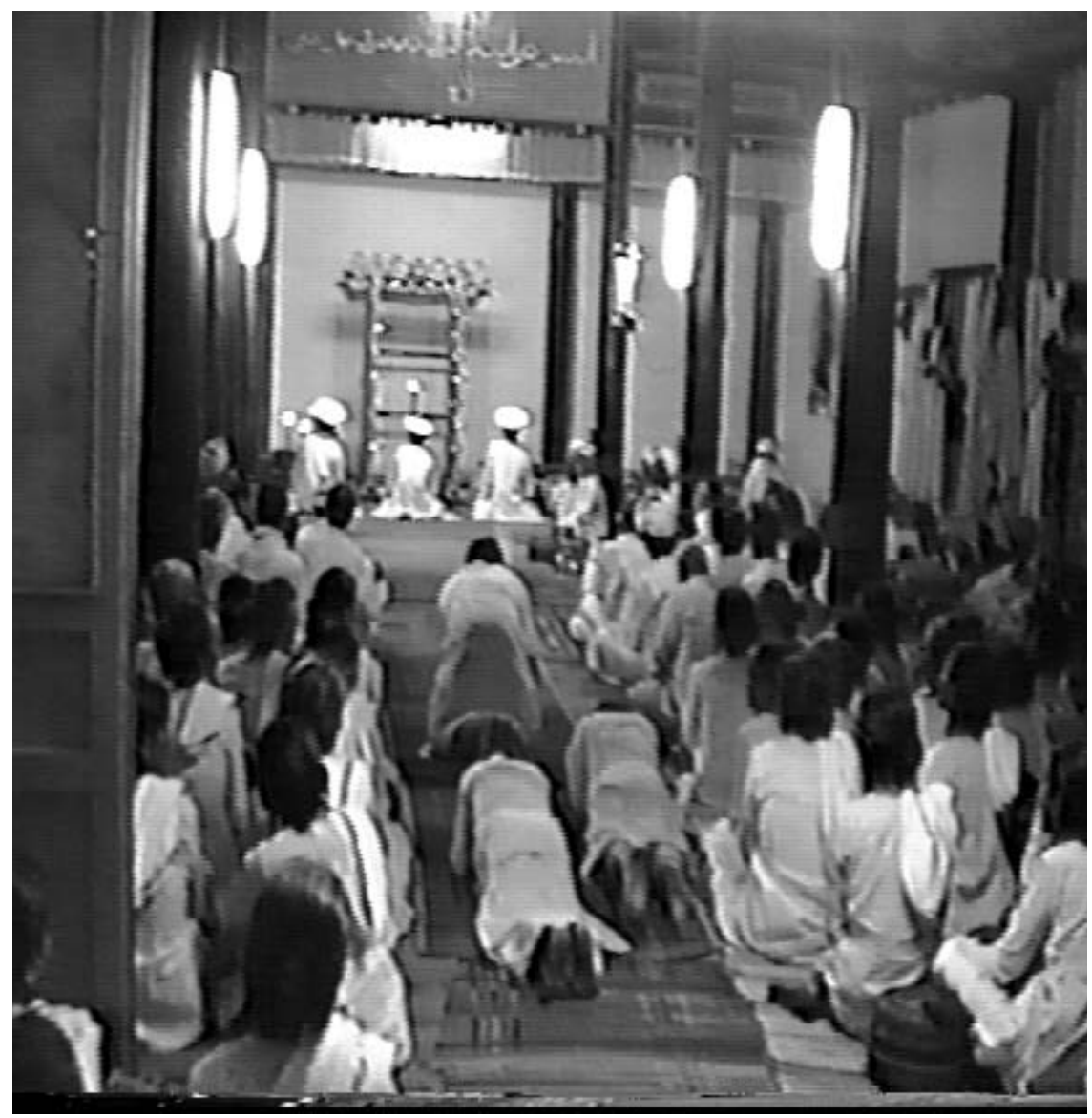

